\title{
THE IMPACT OF AIRPORT DEVELOPMENT ON THE TOURISM IN THE GREEK ISLANDS OF THE SOUTH AEGEAN SEA
}

\author{
Athanasios Ballis (corresponding author) \\ National Technical University of Athens, Athens, Greece \\ Despoina Tsouka \\ Civil Aviation Authority, Helliniko, Greece \\ Tatiana Moschovou \\ National Technical University of Athens, Athens, Greece \\ George Kasselouris \\ National Technical University of Athens, Athens, Greece
}

\begin{abstract}
The current work focuses on the islands of the South Aegean and attempts to highlight the importance of airport infrastructure for their tourism development. The impact of other island characteristics (area, shore length, population, number of beds in various classes of accommodation, cost of accommodation, island's attractiveness, distance from Piraeus port, etc.) was also investigated using regression analysis. The results revealed that airports having runways above $1,800 \mathrm{~m}$ serve direct international flights and have a very significant contribution to the tourism development of the associated islands. On the contrary, islands having airports with short runways are served through Athens International Airport yet, the number of tourist arrivals by air is low, having a minor impact on their tourism product. The characteristics of these islands indicate that they have strong potential for further tourism growth given that their airport infrastructure will be improved overcoming technical and environmental barriers.
\end{abstract}

\section{KEYWORDS}

Tourism, Islands, Greece, Transportation Infrastructure and Services, Regression Analysis

Dr Athanasios Ballis is an Associate Professor at the Department of Transportation Planning and Engineering, National Technical University of Athens, Greece, Email: abal@central.ntua.gr Dr Despoina Tsouka works in the Technical Services Division, Directorate General of Air Transport, Civil Aviation Authority, Helliniko, Greece.

Dr Tatiana Moschovou is a Laboratory Teaching Staff at the Department of Transportation Planning and Engineering, National Technical University of Athens, Greece.

George Kasselouris is a researcher within the Department of Transportation Planning and Engineering, National Technical University of Athens, Greece. 


\section{INTRODUCTION}

Greece is a small country of about 11 million inhabitants with $15 \%$ of them living in more than 220 inhabited islands. Greece has a long coastline, washed by three main seas: the Sea of Crete to the south, the Ionian Sea to the west and the North and South Aegean Sea to the east. At the region of South Aegean (see Figure 1) there are 79 islands geographically and administratively divided into the prefecture of Cyclades (with the islands of Naxos, Andros, Tinos, Paros, Kea, Milos, Amorgos, Ios, Syros, Kythnos, Mykonos, Sifnos, Serifos, Thira, Sikinos, Kimolos, Folegandros, Anafi, Antiparos and many smaller ones) and the prefecture of Dodecanese (with the islands of Patmos, Astypalaia, Leros, Kalymnos, Kos, Nisiros, Chalki, Tilos, Simi, Rhodes, Karpathos, Kasos, Kastelorizo, Leipsi, Agathonisi, etc.). Airports exist in six of the islands of Cyclades, namely Milos, Mykonos, Naxos, Paros, Thira and Syros as well as in eight islands of Dodecanese (Astypalaia, Kalymnos, Karpathos, Kasos, Kastelorizo, Kos, Leros and Rhodes). The existence of such a significant number of airports in the region can be justified by the needs of time-sensitive passengers and cargoes as well as by excessive tourism demand.

\section{Figure 1 - South Aegean Region depicting Islands with Airports having Airport Services and Islands with no Airport Connections}

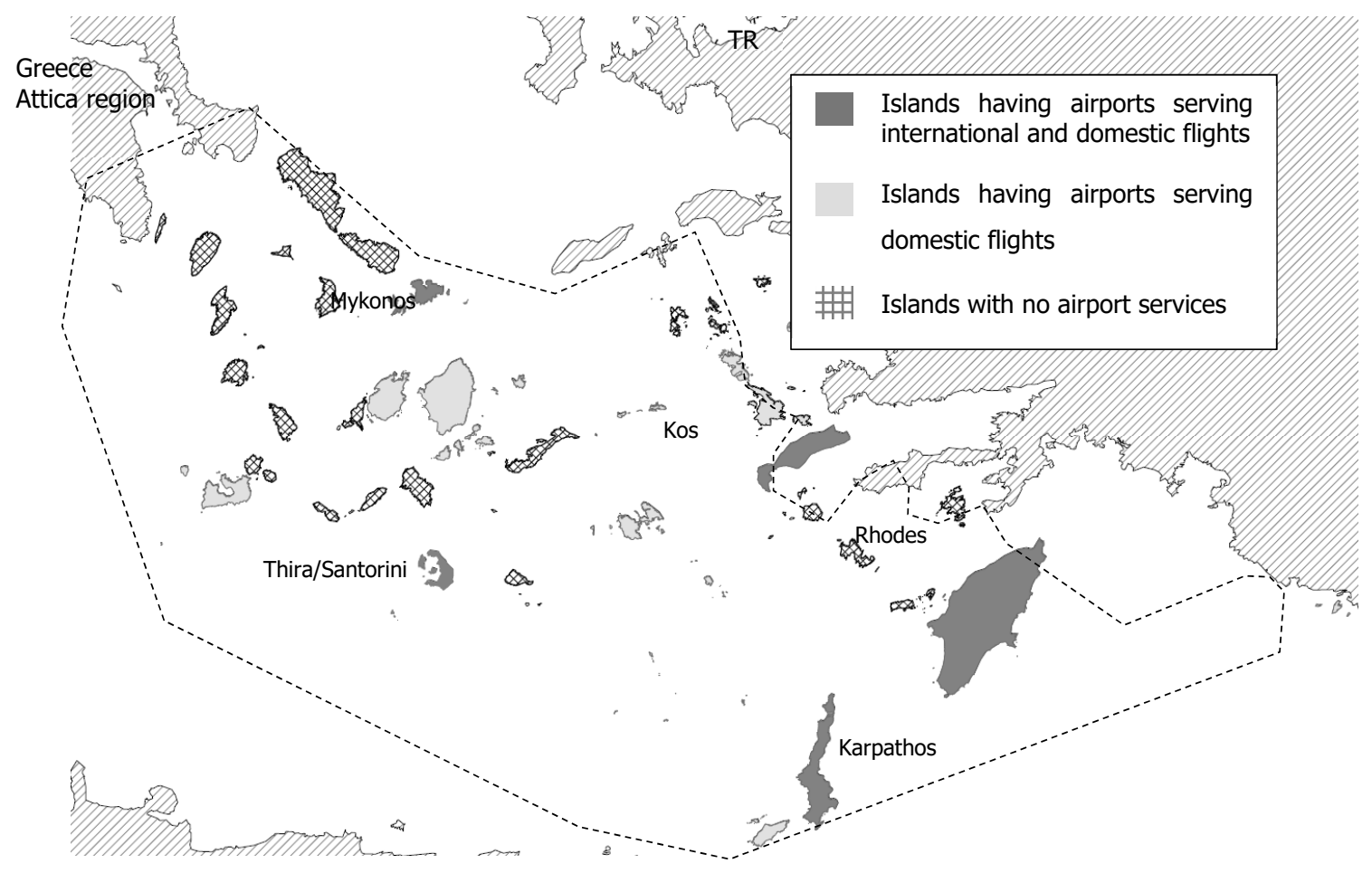


Table 1 presents the volumes of domestic and international tourist passengers that flew from/to each of the above airports during 2016. Tourism is a major economic contributor in S. Aegean region. According to 2017 data (Ikkos and Koutsos, 2018) the tourism sector directly contributed a 77\% of the region's GDP, having the highest per capita GDP. Table 1 also presents the volumes of cargo and mail transported, which are quite low if compared to the total volume of 90,380 th of cargo and 10,850 tn of mail, transported via all Greek airports (mainly via airports of Athens and Thessaloniki). Further analysis revealed that Rhodes airport acts as cargo and mail distributor to other island airports with a total outbound cargo of 110 tn (to Karpathos, Chania, Sitia, Kos, Kasos and Kastelorizo) and 73.5 th of outbound mail (to Karpathos, Kasos and Kastelorizo). The inbound cargo is only 6.8 th originated from Karpathos, Kos and Samos airport.

Table 1 - Tourist Arrivals, Cargo and Mail in Airports of South Aegean, 2016

\begin{tabular}{|c|c|c|c|c|c|c|c|}
\hline \multirow[b]{2}{*}{ Airport } & \multirow[b]{2}{*}{ Code } & \multicolumn{2}{|r|}{ arrivals } & Cargo & (kg) & Mail & (kg) \\
\hline & & International & Domestic & From & To & From & To \\
\hline Karpathos & AOK & 80,545 & 13,620 & 12,434 & 73,200 & 4,355 & 76,190 \\
\hline Kalymnos & $\mathrm{JKL}$ & 0 & 3,570 & 1,409 & 9,770 & 1,480 & 103,480 \\
\hline Mykonos & JMK & 295,352 & 148,711 & 11,816 & 78,213 & 2,103 & 5,145 \\
\hline Naxos & JNX & 0 & 12,135 & 0 & 0 & 0 & 0 \\
\hline Syros & JSY & 0 & 2,406 & 635 & 20,953 & 43 & 12,800 \\
\hline Thira & JTR & 367,388 & 295,632 & 9,859 & 135,036 & 12,475 & 32,489 \\
\hline Astypalaia & JTY & 0 & 3,896 & 0 & 16 & 4 & 0 \\
\hline Kos & KGS & 784,444 & 30,936 & 35,638 & 307,877 & 21,633 & 32,892 \\
\hline Kasos & KSJ & 0 & 879 & 536 & 8,600 & 427 & 28,080 \\
\hline Kastelorizo & KZS & 0 & 2,159 & 97 & 2,266 & 404 & 34,840 \\
\hline Leros & LRS & 0 & 5,278 & 4,051 & 25,330 & 3,892 & 119,490 \\
\hline Milos & MLO & 0 & 15,962 & 1,434 & 44,720 & 129 & 24,400 \\
\hline Paros & PAS & 0 & 22,338 & 0 & 5 & 0 & 1,000 \\
\hline Rhodes & RHO & $1,871,087$ & 83,663 & 113,298 & 724,345 & 74,822 & 29,520 \\
\hline Total & & $3,398,816$ & 641,184 & 191,207 & $1,430,331$ & 121,767 & 500,326 \\
\hline
\end{tabular}

Given the peripheral position of Greece in relation to the Eurozone, air transport is the main transport service for foreign tourists and airports are considered to be the international gateways to the country (Tsouka et al., 2018). The main scope of this paper is to identify the impact of airports as a factor related to the tourism development of the South Aegean islands. The literature review on the subject is presented at Chapter 2. The methodological approach and the content and results of the relevant analysis are presented at Chapter 3 . The last Chapter contains the conclusions. 


\section{LITERATURE REVIEW}

The existing literature on the factors that affect tourism development covers many aspects: tourism infrastructure in terms of services necessary to meet the needs of tourists and increase satisfaction during their stay (Jovanović and Illić, 2016), transport infrastructure and accessibility, accommodation, amenities provided at the destination (Cooper et al., 2008; IATA, 2015; Haneef, 2017), information provided about the destination through official websites (Mak et al., 2012), the sustainability factors and performance of tourism destinations (Gitelson and Crompton, 1984; Diaz and Rodríguez, 2016) as well as the carrying capacity especially in small islands (Saveriades 2008; Briguglio et al., 2002; Hall, 2010) and the effect of overcrowding on tourist attractions (Jiménez and Hernández, 2011). A number of publications concern Greece and Greek islands focusing on the assessment of tourism carrying capacity and highlighting its importance in developing long-term sustainable policies (Tselentis et al., 2006; Coccossis et al., 2002). A recent study about the islands of South Aegean (INSETE, 2015) identified the main purposes of tourists visiting South Aegean Islands (enjoy the sun and sea, visiting friends and relatives, discovering landscape and nature, culture and religion, etc.). Sotiriadis and Varvaressos (2015) analysed the current situation and the problems faced for leisure tourism selecting Greece as a destination in order to formulate recommendations for other countries. A number of researchers focus on the comparison of alternative tourism destinations, among them the study of Pappas (2005) for the urban island host destinations in the Mediterranean region and the paper of Serra et al., (2014), which performed a comparative analysis of tourism destination demand in Portugal. Other researchers deal with issues of tourism competition between countries such as the Mediterranean countries (Patsouratis et al., 2005; Quintiliani, 2009; Sánchez et al., 2015).

Several methodologies have been used to model tourism attractiveness and competitiveness. Du Cros (2001) explored the relationship between cultural heritage destinations and tourism, and developed a methodology procedure to classify cultural assets based on their physical status and market attractiveness. McKercher and Ho (2006) extended the previous research by introducing additional assessment criteria, such as the size and scale of the site, physical and market access, and attractiveness. Several quantitative methods have been applied to evaluate tourism potential. Mamun and Mitra (2012) used multicriteria techniques to quantify social and physical attributes of tourism potential, and applied the methodology to an area of India. The multicriteria approach has been adopted by other authors: Ilban and Yildirim (2017) assessed the tourism performance of 15 countries that are the most popular global tourist destinations. Similarly, Shamai and Mosivand (2011) used multicriteria methods to study the factors that attract tourists to a destination, and determined the hierarchy of towns based on 
these factors. The factors assessed for each town included: hotels; motels; suburban units; restaurants; tour and travel agencies; travel service offices; transportation companies; art galleries and cultural exhibitions; public parks; number of public transport systems; special tourism areas; and capitalization opportunities.

Vengesayi (2003) used the popularity of tourist destinations to formulate a holistic model, the Tourism Destination Competitiveness and Attractiveness Model, by proposing the reputation, branding, destination experience, and cost trip as main input factors. Baldigara and Koić (2015) modelled the international tourism demand in Croatia using regression analysis. The regression analysis was also used by other authors for the investigation of tourist demand in other countries (Naude and Saayman, 2005; Cankurt and Subai, 2015; Tularam et al., 2012).

Many publications in scientific journals or in tourism magazines, especially from less developed countries, have highlighted the strong interrelationship between air connectivity and the successful national or regional tourism growth (UNWTO and ICF, 2016; OECD/ITF, 2018; Dimitriou and Sartzetaki, 2018; Malta Profile, no date) or the need to develop air connectivity as a necessary tool for the development of tourism (Maslen, 2016) or even as an excuse (the luck of sufficient air connectivity) to justify the low level of tourism in certain areas of their countries (Business Line, 2018). Among them, Iñiguez et al., (2014) used complex network theory techniques to investigate the implications of air connectivity for tourism, while Akça (2018) compared the connectivity competitiveness for a number of selected airline hubs by use of computational analysis as well as sensitivity analysis for the investigation of connectivity measure under different factors and practical scenarios of real life.

\section{INVESTIGATION OF TOURISM DEVELOPMENT FACTORS}

The multi-island character of Greece and its strong dependency on tourism requires a complex network of maritime and air services. A significant number of coastal shipping services connect the islands with mainland ports yet, only a small percentage of these are serving the islands directly. Most islands are served through round trips (e.g. Piraeus, Paros, Naxos, Ios, Thira) having long travelling times (e.g. Naxos 3.5 to 6 hours depending on vessel type, Amorgos 9.5 hours, Sikinos 10 hours, Rhodes 15 16 hours, etc.). This is especially true for the islands in the final leg of the trip as due to the procedures that are taking place in all previous island ports (ship docking, passenger embarkation/disembarkation, sailing) the travel time becomes long. Another major problem arises due to the strong dependency of islands on national and international tourism leads to strong seasonality: international tourist flows are concentrated in the period from May to September while domestic tourist flows have a stronger 
concentration around August. As a result, the passenger flows in some islands are dramatically reduced during the winter period, making the associated transport services non-profitable thus asking for State subsidies (Public Service Obligations) in order to ensure an adequate level of service for coastal shipping as well as for air services.

Furthermore, there is a lack of systematic and accurate data and information concerning the movements of national and international passengers and cargoes within the country, which makes difficult the investigation of transport-related issues. For that reason, the data collection was a very challenging task in the current work as the required data had to be retrieved from various sources namely the Hellenic Civil Aviation Authority (HCAA), the Athens International Airport (AIA), the Ministry of Mercantile Marine, Aegean and Island Policy, the Department of Balance of Payment of the Bank of Greece, actors of Greek tourism market like the Greek Tourism Confederation (SETE) and INSETE (a non-profit organisation founded on the initiative of the SETE) as well as from Centre of Planning and Economic Research (Tsekeris and Skoultsos, 2015).

According to the analysis conducted by INSETE (2015), the main tourism markets for Dodecanese are the United Kingdom, Germany, Russia, Italy, the Netherlands and Sweden, while for Cyclades are the United Kingdom, Germany, Italy, France, the USA and Australia. Table 2 presents the Origin - Destination matrix of the international passengers arriving at the islands of Thira and Mykonos for the Cyclades complex and Rhodes, Kos and Karpathos for the Dodecanese complex. The vast majority of these tourists are visiting the above islands using direct flights. A relatively small percentage (less than $10 \%$ ) firstly flies to Athens for a short stay and then travels to Greek islands using domestic flights or shipping lines through Piraeus port (the term "Athens first" tourists will be used hereinafter to distinguish this category of international tourists arriving by air). These tourists have the option to visit Greek islands that do not have airport. Table 2 allows for the identification of tourist's preferences in relation to Greek islands and of gaps (defined here as the missing markets) for certain islands. There is a strong preference of British for Rhodes while Germans preferably choose Rhodes and secondly Kos. On the other hand, Karpathos does not seem as a preferred destination by the British or French travelling directly to them by air. Cases like this can be interpreted as market gaps or differently as market opportunities. Nevertheless, such a variance is understandable and is related to the specific preferences of each nationality (as the relevant literature works indicate) as well as to the deals and traditional alliances of tour operators with accommodation owners. Another explanatory reason could be the air distance of the country from Greece in relation to airplane type used and airport's runway length (Ballis and Paravantis, 2018). 
So, although accurate information exists for the tourists visiting Greece by direct international flights to Aegean islands (that have airport), there is no clear information about the "Athens first" tourist category. These tourists are not distinguished from domestic visitors (tourists and excursionists that travel to islands for leisure) or islanders (traveling from/to Athens for business or social purposes).

In addition, there are no data from shipping lines other than the total number of passenger embarkation and disembarkation in each port (per three month period). Data for tourism obtained from INSETE provide detailed information concerning the bookings of Greek and international tourists in the hotels of each prefecture (INSETE, 2015; Pantelidis and Kouvatseas, 2006), but not for other lodgings (rooms to rent, camping, hospitality to friends, cruise ships, etc.). The capacity (number of beds) of hotels and rooms for rent is known, yet the separation of domestic and international tourists is known only for the hotels. Also, there is no distinction between domestic tourists (who spend one or more days in the islands) and domestic excursionists (who stay less than 24 hours).

In the case of neighbouring islands, like Paros and Antiparos, the number of native population and national/international excursionists travelling between the islands is quite big (and not been distinguished from the tourists/excursionists). That is valid also for many Greeks living in the mainland, but having summer-houses in the islands (which they visit frequently) as well as for residents of islands travelling to other islands for business and social purposes.

The lack of origin-destination data in the coastal shipping services required the development of a gravity model (Ortuzar and Willumsen, 2011) that was used also to estimate the domestic and international tourist flows based on various assumptions. For example, the number of islanders travelling from/to Piraeus was estimated considering the traffic of winter period, where negligible tourists are visiting the islands. However, this is not valid for the cosmopolitan Mykonos and Thira islands that have tourists all over the year therefore, for these islands, other assumptions (based on hotel utilization data for winter) were used.

The analysis concerned the period April to September where the vast majority of International (mainly European) tourists are visiting Greece and show that 3.4 million tourists are flying directly to the islands of South Aegean and 0.6 others are flying to Athens International Airport to be mixed with the 2.8 million Greeks (and other tourists entering the country by sea or land border points) that to their vacation destinations to South Aegean islands. There are also 0.8 million movements of tourists and visitors circulating among the islands of the region, by sea. 
Ballis et al.

Table 2 - Origin/Destination Matrix of International Passengers Arrivals in the South Aegean Islands by Direct Flights in 2016

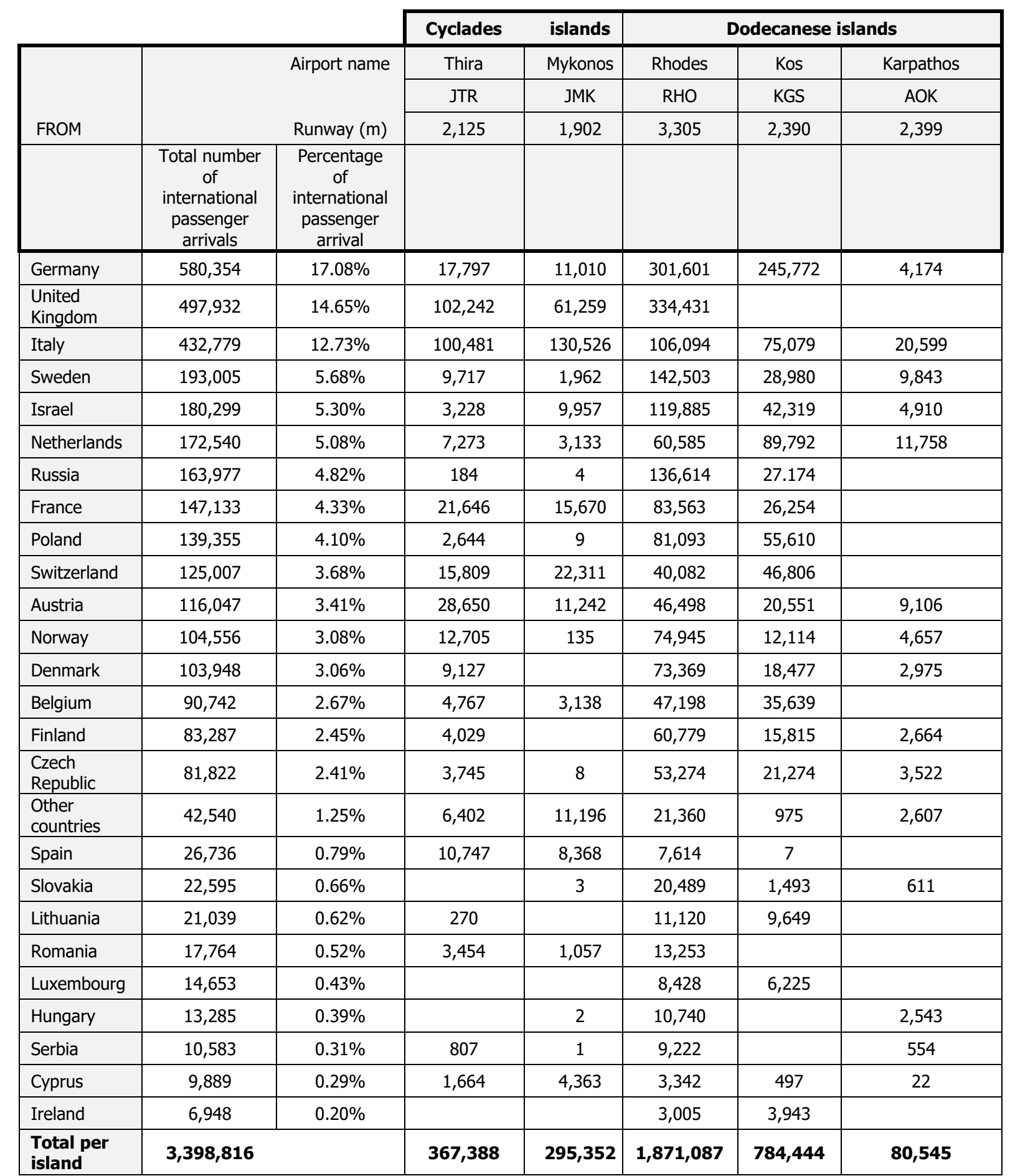

Table composed by the authors based on data retrieved from Hellenic Civil Aviation Authority database

Furthermore, simple and multiple regression analyses were performed. The simple regression analysis aimed to identify relations between factors namely the number of tourists, the area of the island, the coastline of the island, its population, the total number of beds, the number of beds in top categories (more than 4 "stars" for the hotels and more than 3 "keys" for the apartments), the existence of airport (and its runway length), etc. Table 3 presents some of 
this data (area, population, total number of hotel and rooms beds, airport infrastructure and national and international tourists and visitors) for each island of South Aegean region.

Table 3 also provides evidence for the relation between tourists' volumes and the existence of an airport on the island. There are four clusters: the first cluster includes the islands of Rhodes, Thira, Mykonos and Kos that have many tourists and visitors. The airports of these islands have sufficient runway length, allowing for direct international flights from Europe. The second cluster includes the islands of Paros, Naxos, Syros, Tinos, Andros, Milos, Ios, Karpathos and Sifnos where there are no direct international flights and tourist volumes are moderate. The islands of Paros, Naxos and Syros have airports yet, with insufficient runway length for international flights. The runway extension in Paros in 2016 from $710 \mathrm{~m}$. to 1,400 metres has already (September 2018) demonstrated a spectacular increase in tourist arrivals by air (the airport's traffic has been doubled and is expected to be further increased). The length of the runway of Karpathos airport allows for international flights yet, its declared capacity is very low (due to the presence of military operations). Andros and Tinos have no airport, but the islands are close to Piraeus Port and have relatively short travel times by sea. Milos, Ios and Sifnos have no airport and are in medium distance from Piraeus Port.

The third cluster contains 14 islands of medium size, most of which have no airport. Even in islands with airports, the runway length allows only domestic flights. Tourist volumes are low and the existence of an airport does not seem to have an impact on the magnitude of tourism. Finally, the last cluster incorporates six very small islands (Kimolos, Sikinos, Kastelorizo, Kasos, Chalki, Agathonisi) with no airports or airports with very short runways that can serve only small aircraft. These islands have very few tourists and visitors.

The simple regression analysis was used in order to create diagrams between factors involved in tourism development. The upper part of Figure 2 shows the relationship between the number of tourists and visitors during the summer period and the area of the island $\left(\mathrm{Km}^{2}\right)$. The size of the island seems to affect the number of tourists, yet there are many outliers (Thira, Mykonos, Kos, Paros) that have a significant number of tourists in relation to their size. Such significant deviations are explained through other factors of the analysis, e.g. the glamor of Thira and Mykonos islands. On the contrary, islands like Karpathos and Naxos seem to have moderate tourism (or under an optimistic view, high potential to increase their current level of tourism). The area of the island seems to be related with the population (see the lower part of Figure 2) although islands like Syros and Kos (high population in relation to their size), Naxos, Karpathos and Andros (low population in relation to their size) are outliers. 
Table 3 - Area, Population, Total Number of Hotel and Rooms Beds, Airport Infrastructure and National and International Tourists and Visitors

\begin{tabular}{|c|c|c|c|c|c|c|}
\hline & Area $\left(K m^{2}\right)$ & $\begin{array}{c}\text { Population } \\
\text { (1) } \\
\end{array}$ & $\begin{array}{c}\text { Number of } \\
\text { beds } \\
(2)\end{array}$ & $\begin{array}{c}\text { Runway } \\
\text { length }(m) \\
(3)\end{array}$ & $\begin{array}{c}\text { National and } \\
\text { international } \\
\text { tourists }(4)\end{array}$ & Clusters \\
\hline Rhodes & 1,407 & 115,490 & 104,262 & 3,305 & $2,070,000$ & \multirow{4}{*}{$\begin{array}{l}\text { Islands with significant } \\
\text { tourist volumes and } \\
\text { airports serving direct } \\
\text { international flights }\end{array}$} \\
\hline Thira & 71 & 15,550 & 34,318 & 2,125 & $1,205,000$ & \\
\hline Mykonos & 105 & 10,134 & 20,740 & 1,902 & 925,300 & \\
\hline Kos & 288 & 33,388 & 55,583 & 2,390 & 911,500 & \\
\hline Paros & 198 & 14,926 & 17,084 & 1,400 & 533,600 & \multirow{9}{*}{$\begin{array}{l}\text { Islands with moderate } \\
\text { tourist volumes and } \\
\text { airports not serving } \\
\text { direct international } \\
\text { flights (with the } \\
\text { exception of } \\
\text { Karpathos) }\end{array}$} \\
\hline Naxos & 498 & 18,904 & 14,545 & 900 & 280,100 & \\
\hline Tinos & 197 & 8,636 & 5,018 & No & 265,900 & \\
\hline Andros & 381 & 9,221 & 4,448 & No & 147,300 & \\
\hline Syros & 102 & 21,507 & 6,458 & 1,080 & 133,200 & \\
\hline Milos & 168 & 4,977 & 5,424 & 795 & 129,600 & \\
\hline Ios & 109 & 2,024 & 4,556 & No & 107,700 & \\
\hline Karpathos & 324 & 6,226 & 7,513 & 2,399 & 104,000 & \\
\hline Sifnos & 78 & 2,625 & 4,422 & No & 87,600 & \\
\hline Kalymnos & 135 & 16,179 & 2,791 & 1,015 & 65,200 & \multirow{14}{*}{$\begin{array}{l}\text { Islands with low } \\
\text { tourist volumes. Most } \\
\text { islands have no } \\
\text { airport. In islands with } \\
\text { airports the runway } \\
\text { length allows only for } \\
\text { domestic flights }\end{array}$} \\
\hline Patmos & 45 & 3,047 & 2,894 & No & 61,300 & \\
\hline Kythnos & 100 & 1,456 & 1,589 & No & 56,700 & \\
\hline Amorgos & 129 & 1,973 & 2,522 & No & 51,700 & \\
\hline Serifos & 76 & 1,420 & 1,656 & No & 50,200 & \\
\hline Kea & 149 & 2,455 & 1,248 & No & 48,000 & \\
\hline Antiparos & 46 & 1,211 & 1,794 & No & 42,800 & \\
\hline Leros & 75 & 7,917 & 1,999 & 1,012 & 38,200 & \\
\hline Folegandros & 33 & 765 & 1,548 & No & 37,500 & \\
\hline Symi & 65 & 2,590 & 930 & No & 29,700 & \\
\hline Astypalaia & 114 & 1,334 & 1,558 & 989 & 23,500 & \\
\hline Nisyros & 49 & 1,008 & 305 & No & 14,100 & \\
\hline Tilos & 63 & 780 & 975 & No & 13,200 & \\
\hline Anafi & 41 & 271 & 233 & No & 10,000 & \\
\hline Kimolos & 56 & 910 & 265 & No & 8,200 & \multirow{6}{*}{$\begin{array}{c}\text { Very small islands with } \\
\text { very low tourist } \\
\text { volumes and airports } \\
\text { that can serve small } \\
\text { aircrafts }\end{array}$} \\
\hline Sikinos & 43 & 273 & 370 & No & 7,300 & \\
\hline Kastelorizo & 12 & 492 & 306 & 798 & 6,100 & \\
\hline Kasos & 71 & 1,084 & 188 & 983 & 4,300 & \\
\hline Chalki & 37 & 478 & 279 & No & 4,300 & \\
\hline Agathonisi & 15 & 185 & 28 & No & 2,400 & \\
\hline
\end{tabular}

Source: (1) Hellenic Statistical Authority, (2) SETE, (3) Hellenic Civil Aviation Authority, (4) Elaborated using data from Hellenic Civil Aviation Authority (international aviation arrivals), Athens International Airport, passenger shipping lines (passenger boarding / disembarking per port) and data for tourist accommodation combined with assumptions made by the authors

From a mathematical point of view there is a moderate correlation between the number of tourists/visitors and the area of the island as well as between the number of tourists/visitors and the coastline length or the population of the island $\left(R^{2} \sim 0.5\right)$. Strong relationship $\left(R^{2} \sim\right.$ 0.85) was found between the number of tourists and the number of beds, which, however, cannot be used as an explanatory variable for the number of tourists (although there is a general relationship between supply and demand, providing more beds on an island does not necessarily mean that tourists will grow accordingly). 
Finally, two multiple regression models were developed. The first model has as a dependent variable the number of visitors/tourists and as independent (explanatory) variables the population of the island, the percentage of beds of 4 and 5 stars hotels in relation to the total number of beds of the island's hotels (as an indicator of the island's glamorous), the duration of the trip by ship from Attica ports and the airport runway length (zero in the case of absence of an airport). The "island" and "coastline" variables are not included because of their high correlation with the population variable. All coefficients of the explanatory variables have a positive sign, with the exception of the trip duration that has a negative sign as the travel time is a limiting factor for visitors/tourists traveling by sea. This model is simple and comprehensible and has a high correlation coefficient $\left(R^{2}=86.7 \%\right.$, adjusted $\left.R^{2}=84.8 \%\right)$, although from a statistical viewpoint some requirements are not satisfied to the desired extent. The second model is more complex as it uses natural logarithms for both the independent variable (ratio of visitors/tourists per island area) and the explanatory variables that are the natural logarithms of the ratio of population per island area, the ratio of coastline per island area, the average rooms' prices, Google hits (as an indicator of how known each island is) and trip duration. There are two dummy variables, one for the existence of an airport on the island and the other showing if the runway length is more than 1,800 meters. The model is statistically correct (VIF for all variables is less than 3.5 with the limit to 5 , and the p-values less than 0.05 , satisfactory results in residuals analysis) and has a high correlation coefficient $\left(R^{2}=89.9 \%\right.$, adjusted $\left.R^{2}=87.1 \%\right)$ (Ballis et al., 2018).

In both multiple regression models, the runway length is an explanatory variable (affecting mainly the international tourists). The runway length restricts the type and size of aircraft to be used which in turn, affects the airport's catchment area and the economy of flights. ICAO defines four Categories: in Category 3, the airplane reference field length is between $1,200 \mathrm{~m}$ and $1,800 \mathrm{~m}$ while in Category 4 this length is more than $1,800 \mathrm{~m}$. Upgrade to a higher Category imposes much more requirements (runway width, safety strips, etc.) and for that reason, reaching the limits of each Category is the only pragmatic solution. It must be noted that not all airport runways can be extended due to various restrictions (obstacles, land availability, etc.). Another step of the analysis was related to the types of aircraft landing/taking-off to island airports and showed that Boeing 737-800 and Airbus A320 dominate as they account for $55 \%$ of all aircraft with the A320 having a slightly larger share than B737-800. These aircrafts require a considerable length of runway for their take-off and therefore it is not possible to operate on islands with runways of ICAO Category 1, 2 and 3, which are served by aircraft with lower capacity and aircraft range such as AT72 and DH8D (serving mainly category 
3 airports) as well as the smaller AT43 and D8A types that seem to be able to take off from all the island airports of South Aegean.

Figure 2 - Tourists vs Area (upper part) and Area vs Population (lower part) for the South Aegean Islands. Rhodes Island is not depicted, data 2016

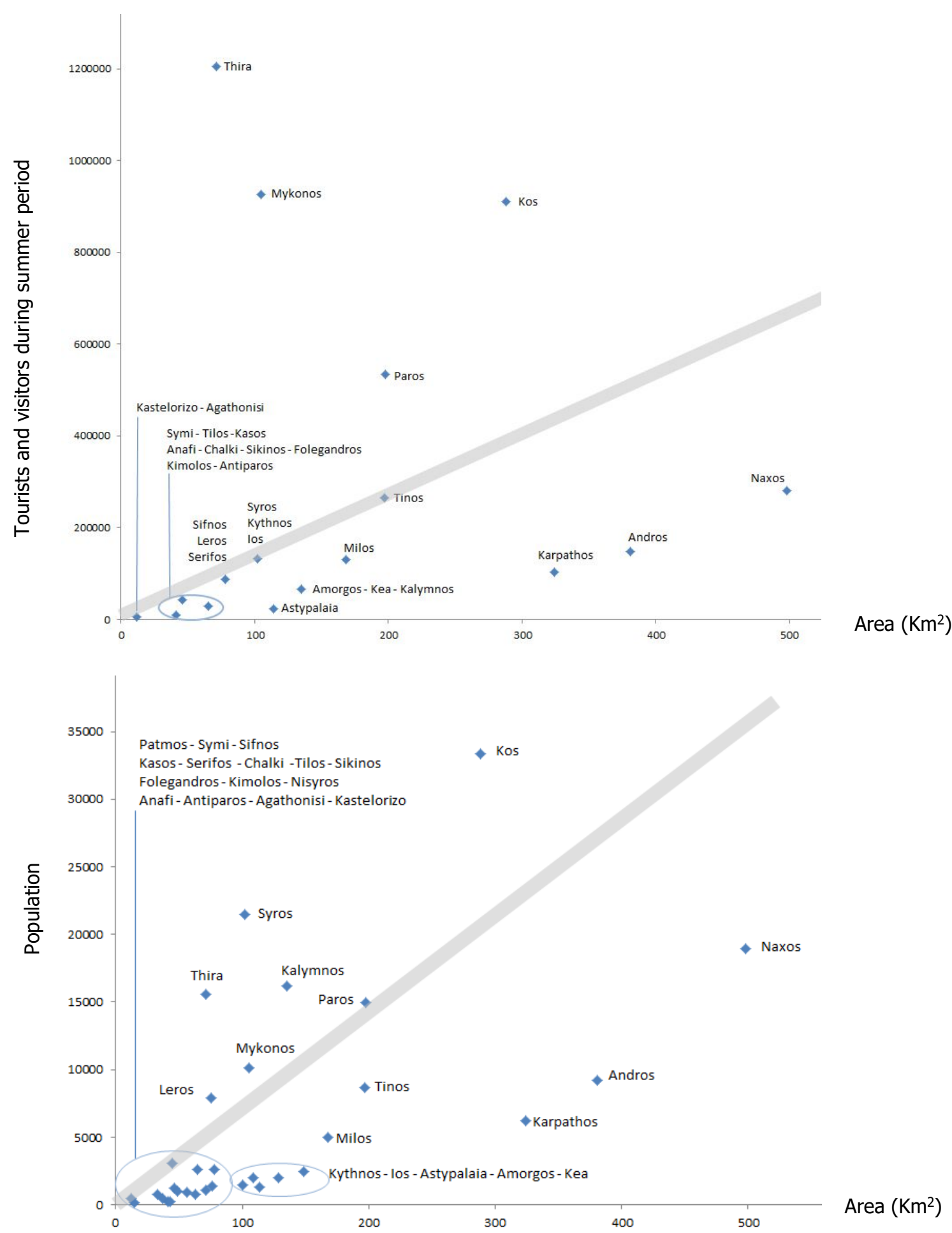

This analysis also revealed some techniques used by airlines such as the Amsterdam - Kythira

- Kalamata - Amsterdam flight with Boeing 737. This aircraft can land and take-off from the 1,461 meter runway of Kythira airport (as it carries a small quantity of fuel) to fly to the nearby 
airport of Kalamata. Upon landing to Kalamata, the aircraft can be refuelled and take off again to Amsterdam using the 2,703 meter runway of Kalamata airport, which is adequate for the take-off of the aircraft at full load (all passengers plus a significant quantity of fuel required for the long haul trip to Amsterdam).

Without neglecting or underestimating the potential of any of the South Aegean islands to improve its touristic performance, the analysis concluded that the islands of Karpathos, Paros, Naxos, Milos, Kalymnos and Astypalaia have a stronger potential to increase their current tourism volumes. Airport infrastructure can contribute in this direction especially for Paros, Naxos, Milos and Kalymnos where airport's runways are short and can be extended. However, runway extension can be restricted by the geomorphology of the area (Astypalaia, Kalymnos), proximity of protected and residential areas (Naxos) or protests of groups of inhabitants that are opposed to such a project claiming environmental problems (Milos, further extension of runway in Paros). A balanced approach is required based on fair assessment of all pertinent factors.

Another issue that should not be neglected from such an analysis is the ability of airports, islands and the tourist product in general. There are airports in Greece that reach their limits such as the airports of Heraklion, Corfu and Rhodes, which operate at their maximum declared hourly capacity during the day and have also a significant number of flights during the night. Limits also exist on the island's carrying capacity (an issue that is often found in the international bibliography), and there are already reports in the international press (about the depletion of infrastructure in the busy Greek islands) that encourage tourists in their countries to search for other less touristic and less developed islands in Greece to avoid overcrowding. This fact can also be seen as a development opportunity for the less developed islands, although, in a country in economic crisis, the discussion of the carrying capacity of islands and coastal areas cannot be done in a hospitable environment (Lialos, 2017). Finally, with regard to the tourism product, it should be understood that other Mediterranean countries offer also sun and sea (Spain, Portugal, France, Italy, Croatia, Cyprus, Malta, Turkey, Egypt, etc.). These countries continue to invest in their hotel and transport infrastructure and strive to improve the quality of their tourism services creating a very competitive market (Patsouratis et al., 2005; Quintiliani, 2009; Sánchez et al., 2015).

\section{CONCLUSIONS}

Tourism is important for the economy of the South Aegean islands. There are several factors that affect the tourism development. In the current work the investigation of the relationships 
between the number of tourists with some explanatory variables such as island area, length of coastline, population, number of beds of hotels and rooms to rent, number of beds of 4 and 5 star hotels (as an indirect indicator of the quality of the tourist infrastructure), average rooms price, island attractiveness, distance from Piraeus port as well as port and airport infrastructure. A regression-based analysis showed that there is significant growth potential for tourism in some, less developed islands where airport runways are small and can (where appropriate) be expanded. In such a case, significant obstacles will have to be overcome in terms of both geomorphology and technical issues, as well as of complains of groups of residents who protest claiming environmental issues. Indeed, there are limits to the airports' development, the island's tourism capacity and the tourism product in general due to the competition between countries, and especially between the Mediterranean countries.

\section{REFERENCES}

- Akça Z. (2018). Comparative analysis with a new hub connectivity measure considering revenue and passenger demand, Journal of Air Transport Management, Vol. 67, pp. 3445.

- Baldigara T. and M. Koić, (2015), Modeling the international tourism demand in Croatia using a polynomial regression analysis, Turističko poslovanje, vol. 15, is. 15, pp. 29-38.

- Ballis A., (2007), An overview of air cargo terminal design aspects", Transportation Research Record, Journal of the Transportation Research Board, No 2007, Washington DC, 2007, (pp. 117-125)

- Ballis, A., Paravantis, J. and Moschovou, T. (2018). Assessing the Tourism Potential of the Greek Islands of South Aegean, Approved for presentation at the $9^{\text {th }}$ International Conference on Information, Intelligence, Systems, Applications IISA 2018, 23-25, July, Zakynthos, Greece

- Ballis, A., Paravantis, J., (2018). Airport Data Analysis Using Common Statistical Methods and Knowledge Based Techniques, Forthcoming

- Business Line (2018). With better air connectivity, North -East rising on tourism map. Available online at https://www,thehindubusinessline,com/news/with-better-airconnectivity-north-east-rising-on-tourism-map/article24187253.ece (accessed 20.07.2018)

- Briguglio, L., and Briguglio, M. (2002). Sustainable Tourism in Small Islands: the Case of Malta, Updated version of a paper with the same name published in Sustainable Tourism in Islands and Small States: Case Studies, London, UK: Cassell/Pinter, 1996.

- Cankurt S., and A. Subai, (2015) Tourism demand modeling and forecasting using data mining techniques in multivariate time series: a case study in Turkey", https://doi.org/10.3906/elk1311-134.

- Coccossis, H., Mexa, A., and Collovini, A., (2002). Defining, Measuring and Evaluating Carrying Capacity in European Tourism Destinations, Final Report, B43040/2000/294577/MAR/D2, Athens, Greece.

- Cooper, C., Fletcher, J., Fyall, A., Gilbert D., \& Wanhill, S. (2008). Tourism: Principles and Practice, Essex: Pearson Education Limited, Fourth Edition.

- Diaz, M.R. and Rodriguez, T.F.E. (2016) Determining the Sustainability Factors and Performance of a Tourism Destination from the Stakeholders' Perspective, Sustainability 2016, 8(9), 951. 
- Dimitriou, D. and Sartzetaki, M. (2018) Air Transport Connectivity Development in Tourist Regions, Working Papers 18_1, SIET Società Italiana di Economia dei Trasporti e della Logistica.

- Du Cros, H. (2001). A New Model to Assist in Planning for Sustainable Cultural Heritage Tourism, International Journal of Tourism Research, Vol. 3, pp. 165-170.

- Gitelson, R., J, and Crompton, J.L. (1984). Insights into the repeat vacation phenomenon, Annals of Tourism Research, 11 (2), pp. 199-217.

- Hall, M. C. (2010). Island Destinations: A Natural Laboratory for Tourism Introduction, Asia Pacific Journal of Tourism Research, 15 (3), September 2010, Routledge, Taylor and Francis Group.

- Haneef, S. K. (2017). A Model to Explore the Impact of Tourism Infrastructure on Destination Image for Effective Tourism Marketing, PhD Thesis, School of the Built Environment University of Salford, UK,

- IATA (International Air Transport Association) (2015). IATA Foundation in Travel and Tourism, International Travel and Tourism Training Program, $5^{\text {th }}$ Ed.

- Ikkos A. and Koutsos S. (2018). The contribution of tourism in Greek economy in 2017, 1st Estimation-May 2018, SETE Intelligence (in Greek)

- Ilban M. O. and H. H. Yildirim, (2017), Determination of tourism activities of the world's best tourism destinations using the multi-criteria decision-making method, Cogent Social Sciences, vol.3: 1301763 http://dx.doi.org/10.1080/23311886.2017.1301763.

- Iñiguez, T., Plumed, M., and Martínez, M. P. L. (2014). Ryanair and Spain: Air connectivity and tourism from the perspective of complex networks, Tourism \& Management Studies, Vol. 10(1), pp.46-52. ISSN 2182-8458.

- Institute of Greek Tourism Confederation (INSETE) (2015). Research, Analysis and Mapping of the Tourist Environment of the Southern Aegean Region, project funded by the European Social Fund.

- Jiménez. Y.S., Hernández. J. M. (2011). Estimating the effect of overcrowding on tourist attraction: The Case of Canary Islands, Tourism Management, Volume 32, Issue 2, April 2011, pp. 415-425.

- Jovanović, S., and Ilić, I. (2016). Infrastructure as important determinant of tourism development in the countries of Southeast Europe, ECOFORUM, 5, 1 (8).

- Lialos G, (2017), Tourism exposition brought the collapse of infrastructure (in Greek), Kathimerini 4-9-2017 http://www.kathimerini.gr/925088/article/epikairothta/ellada/htoyristikh-ekrh3h-efere-katarreysh-twn-ypodomwn

- Mak, A., Wu, E. H.C., Law, R. and Wu, W. (2012). Assessing the E-Services of International Airport Websites: Implications for Innovative E-Tourism Applications, Presented at the $11^{\text {th }}$ International Conference on Computer and Information Science, IEEE/ACIS, 30 May-1 June, Shanghai, China

- Malta Profile, (no date), Available online at: https://maltaprofile,info/article/airconnectivity-remains-a-strategic-priority-for-the-tourism-sector (accessed 11.06.2018)

- Mamun Al A., and S. Mitra, 2012, A methodology for assessing tourism potential: case study Murshidabad District, West Bengal, India, International Journal of Scientific and Research Publications, vol. 9, is. 2, pp.1-8.

- Maslen, R. (2016). A Route to success: How global air connectivity drives tourism and economic growth, Visitor Economic Bulletin, February 2016 edition.

- McKercher B. and P.S.Y. Ho, (2006) Assessing the tourism potential of smaller cultural and heritage attractions, Journal of Sustainable Tourism, vol. 14, is. 5, pp. 473-488.

- Naude W. A. and A. Saayman, (2005), Determinants of tourist arrivals in Africa: A panel data regression analysis, Tourism Economics, vol. 11, pp. 365-391.

- OECD/ITF, (2018). Defining, Measuring and Improving Air Connectivity, https://www,itfoecd,org/defining-measuring-improving-air-connectivity 
- Pappas, N., (2005). Mediterranean Tourism: Comparative Study of Urban Island Host Destinations, International Conference on Tourism Development \& Planning, 11 - 12 June, T.E.I. Patras, Greece.

- Patsouratis V., Frangouli Z. and Anastasopoulos G., (2005), Competition in tourism among the Mediterranean countries, Applied Economics, vol. 37, is.16, pp.: 1865-1870

- Pantelidis E. and Kouvatseas G., (2006), Frontier survey on travel expenditure: methodology, presentation and output assessment (2003-2005), Economic Bulletin, Bank of Greece, Number 27, https://www.bankofgreece.gr/BogEkdoseis/econbull200607.pdf

- Ortuzar, Juan de Dios and Willumsen L.G., (2011) Modelling Transport / Juan de Dios Ortuzar, Luis G. Willumsen. - Fourth edition.

- Quintiliani F., (2009), International tourism in the coastal regions of five Mediterranean countries, Tourism Analysis, vol.14, is. 3, pp.: 353-373

- Sánchez Antonio García, López David Siles, (2015), Tourism destination competitiveness: The Spanish Mediterranean case, Tourism Economics, vol. 21, is. 6, pp.: 1235-1254

- Saveriades, A., (2000). Establishing the social tourism carrying capacity for the tourist resorts of the east coast of the Republic of Cyprus, Tourism Management, 21, pp.147-156.

- Serra, J., Correia, A., and Rodrigues, P.M.M. (2014). A comparative analysis of tourism destination demand in Portugal, Journal of Destination Marketing \& Management, 2, pp.221-227.

- Shamai A. and Mosivand J. (2011), Classification of cities of Isfahan province in view point of tourism infrastructure by using TOPSIS and AHP models, Journal of Urban-Regional Studies and Research, vol.3, pp. 23-40.

- Sotiriadis, M., and Varvaressos, S., (2015) A Strategic Analysis of the Greek Leisure Tourism: Competitive Position, Issues and Challenges, Mediterranean Journal of Social Sciences, 6, 1, pp.319-332.

- Tselentis, B. S., Prokopiou, D. G. and Toanoglou, M. (2006). Carrying capacity assessment for the Greek islands of Kalymnos, Kos and Rhodes, WIT Transactions on Ecology and the Environment, 97, WIT Press.

- Tsekeris Th. and Skoultsos S. (2015), Estimation of the Distribution of Revenues from Incoming Tourism, with respect to the part remaining in the country and that re-exported abroad, KEPE, Athens (in Greek)

- Tsouka, D., Ballis, A., Moschovou, T. \& Kasselouris, G. (2018) Assessing the performance of the airports of the Greek islands, Presented at the $5^{\text {th }}$ Aviation Conference-Air Transport of Today and Tomorrow, 14-15 May, Athens, Greece (in Greek).

- Tularam G., V. Wong, and H. Shobeiri Nejad, (2012), Modeling tourist arrivals using time series analysis: Evidence from Australia, Journal of Mathematics and Statistics, vol. 8 is.3, pp.348-360.

- Vengesayi S., (2003), A conceptual model of tourism destination competitiveness and attractiveness, ANZMAC 2003 Conference Proceedings Adelaide, Monash University, 1-3 December 2003, pp. 637-645.

- UNWTO and ICF, (2016), Enhancing Tourism Competitiveness through Improved Air Connectivity, Presented at the International Tourism Fair, Madrid, 20-24 January 2016. 